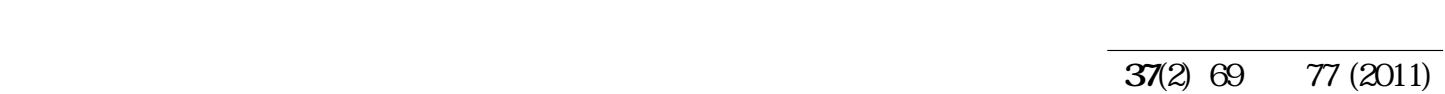

\title{
アスピリンの抗血小板作用に及ぼすロキソプロフェン ナトリウムの影響と炎の回避方法
}

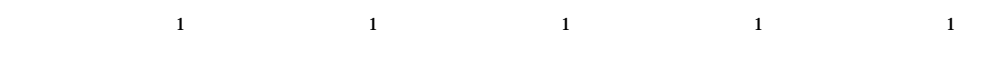
土谷隆紀 ${ }^{12}$, 久保田芳郎 ${ }^{3}$, 青山隆夫 $^{1}$

東京理科大学薬学部 ${ }^{1}$, キッコーマン総合病院薬斉部 ${ }^{2}$, キッコーマン総合病院外科 ${ }^{3}$

\section{Influence of Loxoprofen Sodium on Antiplatelet Effect of Aspirin and How to Avoid this Interaction}

\author{
Yuuki Akagi ${ }^{* 1}$, Kenta Shibata ${ }^{1}$, Shuji Shimada ${ }^{1}$, Akinori Yanaka ${ }^{1}$, Yoshikazu Higami $^{1}$, \\ Yoshinori Tsuchiya $a^{1,2}$, Yoshirou Kubota ${ }^{3}$ and Takao Aoyama ${ }^{1}$ \\ Faculty of Pharmaceutical Sciences, Tokyo University of Science ${ }^{1}$, \\ Department of Pharmacy, Kikkoman General Hospital ${ }^{2}$, \\ Department of Surgery, Kikkoman General Hospital ${ }^{3}$
}

Received A ugust 12, 2010

A ccepted November 23, 2010 )

\begin{abstract}
Low-dose aspirin, an antiplatelet agent, acts by irreversibly acetylating internal cyclooxygenase 1 (COX-1) on platelets, and is effective in the secondary prevention of cardiovascular events. However, as loxoprofen sodium also inhibits COX-1 reversibly, its coadministration with aspirin may suppress the latter's antiplatelet effect. We performed single and multipledaily-dose studies in healthy volunteers to investigate the antiplatelet effect of aspirin when given with loxoprofen sodium and determined a method for avoiding any interaction between the 2 drugs.

We administered aspirin and loxoprofen sodium in the following manner in the single-daily-dose study : aspirin and loxoprofen sodium administered at the same time or with a two-hour interval between them. In the multiple-daily-dose study, drugs were taken for four days as follows: aspirin (after breakfast), loxoprofen sodium (after every meal), both drugs given at the same time in the morning, and taking aspirin before loxoprofen sodium in the morning. We measured platelet aggregation and serum thromboxane $\mathrm{B}_{2}$, and calculated the platelet aggregation threshold index (PATI) as the index of aggrega tion activity, which was defined as the putative stimulus concentration giving $50 \%$ aggregation.

In the multiple-daily-dose study, when both drugs were taken at the same time, the PATI was $2.20 \pm 0.43 \mathrm{~g} / \mathrm{mL}$, suggesting that the antiplatelet effect of aspirin had been decreased due to weak platelet COX-1 inhibition. On the other hand, when aspirin was taken before loxoprofen sodium the PATI was $5.29 \pm 0.59 \mathrm{~g} / \mathrm{mL}$, similar to that for aspirin only $(5.51 \pm$ $0.59 \mathrm{~g} / \mathrm{mL}$ ). Therefore, though the antiplatelet effect of aspirin was suppressed by loxoprofen sodium, this interaction could be avoided by taking aspirin 2 hours before loxoprofen sodium in the morning.
\end{abstract}

Key words — aspirin, antiplatelet, loxoprofen sodium, drug interaction, human, cyclooxygenase 1

緒言

低用量アスピリンに血小板凝集抑制作用が認められる ことが 1967 年に発見されてから ${ }^{11}$, 抗血小板薬としての 有用性は複数の大規模臨床試験によって証明されてき た ${ }^{23)}$. 心筋梗塞の急性期におけるアスピリンの服用は， わが国を含む各国のガイドラインでも広く推奨されてい る4) . アスピリンは血小板シクロオキシゲナーゼ-1 (COX-1)の内部に入り込み，529位のセリン残基を不可
逆的にアセチル化する゙ COX-1の活性中心へ結合できなくなり，アラキドン酸 の代謝産物であるトロンボキサン $\mathrm{A}_{2}\left(\mathrm{TX} \mathrm{A}_{2}\right)$ の合成が抑 制される .アアセチル化された血小板の反応性が回復する ことはないため，アスピリンの影響を受けていない新た な血小板が産生されるまで, 抗血小板作用は持続すると 考えられている。.

一方 , ロキソプロフェンナトリウムをはじめとする非 ステロイド性抗炎症薬(NSAIDs)は, 解熱・鎮痛目的に 多種多樣に用いられている．アスピリンとは異なり， 
医療薬学 Jpn. J. Pharm. Health Care Sci.

COX-1の 120 位のアルギニン残基と塩橋を形成し ${ }^{7}$, プ ロスタグランジン $\mathrm{E}_{2}$ 合成を抑制する . 血小板機能も抑 制するが , NSAIDsの COX-1阻害は可逆的であるため， 薬剂服用後のある一定時間に限られる ${ }^{8)}$.

低用量アスピリンを服用していて，関節炎・関節リウ マチ等の整形外科領域の疾患に伴う鎮痛目的でNSAIDs を併用する患者は多いことが想定される゙9. アスピリン とイブプロフェンとを併用した場合 , アスピリンの抗血 小板作用が減弱することが知られており ${ }^{5,10,11)}$, アスピ リン，イブプロフェン双方の医薬品添付文書上において も注意喚起されている. 兴の機序として，イブプロフェ ンがCOX-1内部に入り込み, アスピリンによるセリン 残基のアセチル化を妨害することでアスピリンの作用を 減弱させることが考えられている5. なお，わが国では イブプロフェンよりもロキソプロフェンナトリウムの処 方量が多いが(2)，ロキソプロフェンナトリウムがアスピ リンの抗血小板作用にどの程度影響があるのかよくわ かっていないため, 詳細な検討が必要である .

光こで本研究では, アスピリンにロキソプロフェンナ トリウムを併用した場合のアスピリンの抗血小板作用へ の影響を，健常成人ボランティアへの投与試験によって 検討した . 初めに , アスピリンとロキソプロフェンナト リウムを単回併用投与した際に, アスピリンの抗血小板 作用を減弱させるか検討した．次に，臨床現場でよく用 いられる投与回数で服用することを想定し，連続併用投 与において，アスピリンの抗血小板作用を減弱させるか 検討した . 最後に，この相互作用を回避する方法につい て考察することを目的とした .

\section{方 法}

\section{1. 被験者}

単回投与試験では 11 名(24.8 6.4 歳)，連続投与試験

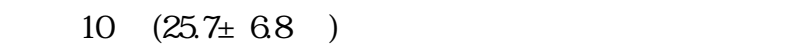
とした.ボランティアに対して事前に説明会を開催し， インフォームドコンセントを取得してから試験を行っ た. 被験者の体重は, 全員とも理想体重の $\pm 30 \%$ 以内 であった . 被験者の中には喫煙者はおらず，試験開始日 の 2 週間以内にアスピリンを，1週間以内にNSAIDsや 抗血小板作用を有する医薬品を服用していないことを確 認した . アスピリンおよびロキソプロフェンナトリウム の禁忌・慎重投与(過敏症既往歴, 消化性潰瘍, 喘息, 血液異常, 肝障害, 腎障害, 心機能異常, 潰瘍性大腸 炎, クローン病等)に該当する場合，アスピリンまたは NSAIDsのいずれも服用したことがない場合，医薬品に 対する何らかの過敏症がある場合は, 試験への参加を見 あわせることとしたが, 除外基準に該当した者はいな かったため，同意が得られた全員が各試験に参加でき た . また，両試験とも副作用等による脱落者はいなかっ た. 本研究は東京理科大学倫理委員会(承認番号 09005)
およびキッコーマン総合病院倫理委員会(承認番号 2)の 承認を受けて実施された .

\section{2. 試験デザイン}

1)単回投与試験

単回投与試験のプロトコールは , アスピリン(1)Asp) またはロキソプロフェンナトリウム単剂服用(2)Lox)の 場合に加えて，両方の医薬品を同時に服用した場合(3) Asp + Lox) , アスピリンの 2 時間後にロキソプロフェン ナトリウムを服用した場合(4)Asp $\rightarrow$ Lox ) , ロキソプロ フェンナトリウムの 2 時間後にアスピリンを服用した場 合(5)Lox $\rightarrow$ A sp)の計 5 条件とし , オープン化されたラン ダム化比較試験(RCT)のクロスオーバー・デザインにて 行った(Fig. 1-A) . 採血の時間は, 最初の医薬品服用の 30 分前, アスピリンを服用してから 4,24 時間後(ただ し , (2)Lox の条件では, ロキソプロフェンナトリウムを 服用してから 4,24 時間後)とし，各条件間の休薬期間は 2 週間以上確保した。

2)連続投与試験

連続投与試験のプロトコールは, Fig. 1-Bに示した . アスピリンを1日1回朝食後(9:00)に4日間服用した 場合(6)A sp 連続)，ロキソプロフェンナトリウムを1日 3 回毎食後 $(9: 00,13: 00,19: 00)$ に 4 日間服用した場 合(7)Lox 連続)に加えて，両方の医薬品を併用して 4 日 間服用した場合の条件を設定した . 具体的には，朝食後 にアスピリンとロキソプロフェンナトリウムを同時(9: 00)に服用した場合(8)Asp + Lox 連続), アスピリンを先 (7：00)に服用して 2 時間後(9：00)にロキソプロフェン ナトリウムを服用した場合(9)A sp $\rightarrow$ Lox 連続)の 2 通り のプロトコールで実施した . 4 日目は，採血の都合で薬 の服用時間を 2〜4時間遅らせ，最後の採血が終了次 第，薬の服用を終了した．医薬品服用前の採血は，被験 者の便を考慮し原則として前日 14:00に行い, 服用後 の採血は，4日目のアスピリン服用(ただし，(7L Lox 連続 ではロキソプロフェンナトリウム服用)の 30 分前(10 : 30)と 4 時間後(15: 00)に行った . 以上の 4 条件をオープ ン化されたランダム化比較試験(RCT)のクロスオー バー・デザインにて行い, 各条件間の休薬期間は 2 週間 以上確保した .

\section{3. 医薬品・試薬}

被験者が服用する医薬品は, バファリン配合錠 A 81 (一般名アスピリン・ダイアルミネート, ライオン(株), Lot. No. 91311)およびロキソニン踶 $60 \mathrm{mg}$ (一般名ロキ ソプロフェンナトリウム , 第一三共(株), Lot. No. THA 2892)を用いた．血小板凝集惹起剂はコラーゲン(アイ・ エム・アイ(株) , Lot. No. C 003)とアデノシンニリン酸 (adenosine 5'-diphosphate disodium salt: ADP, 和光純薬 工業(株)，Lot. No. 105704)を用いた . 谷の他の試薬はす ベて特級を使用した。 
(A) Single-daily-dose study

Asp: Aspirin

Lox: Loxoprofen sodium

(1) Aspirin

(2) Loxoprofen sodium

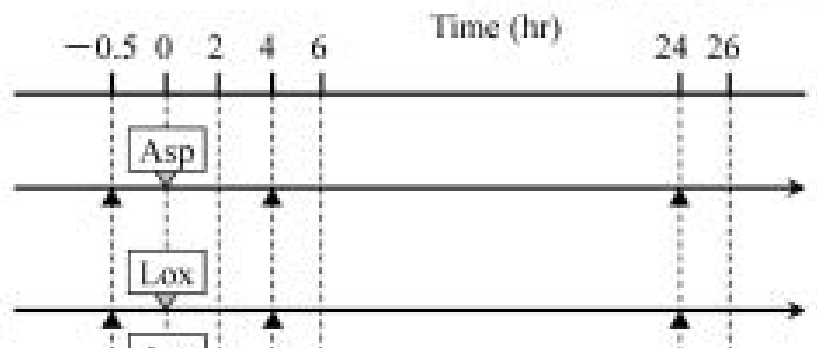

(3) Aspirint

Loxoprofen sodium

(4) Aspirin $\rightarrow$

Loxoprofen sodium

(5) Loxoprofen soxium

$\rightarrow$ Aspirin

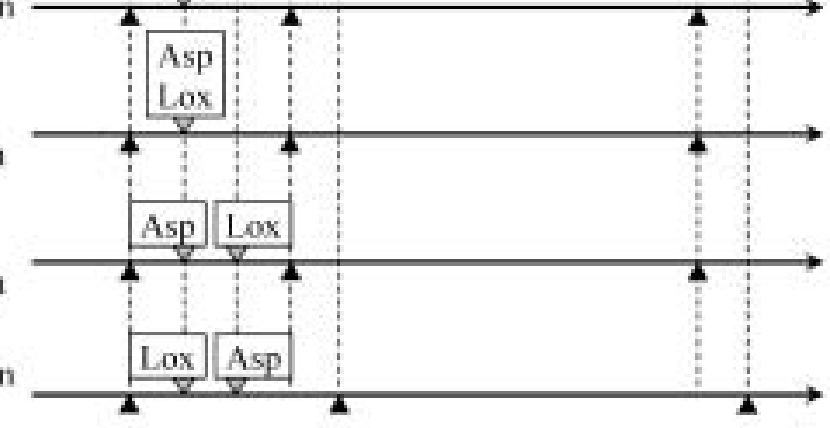

$\nabla:$ Administration

: Blood collection

(B) Multiple-daily-dose study

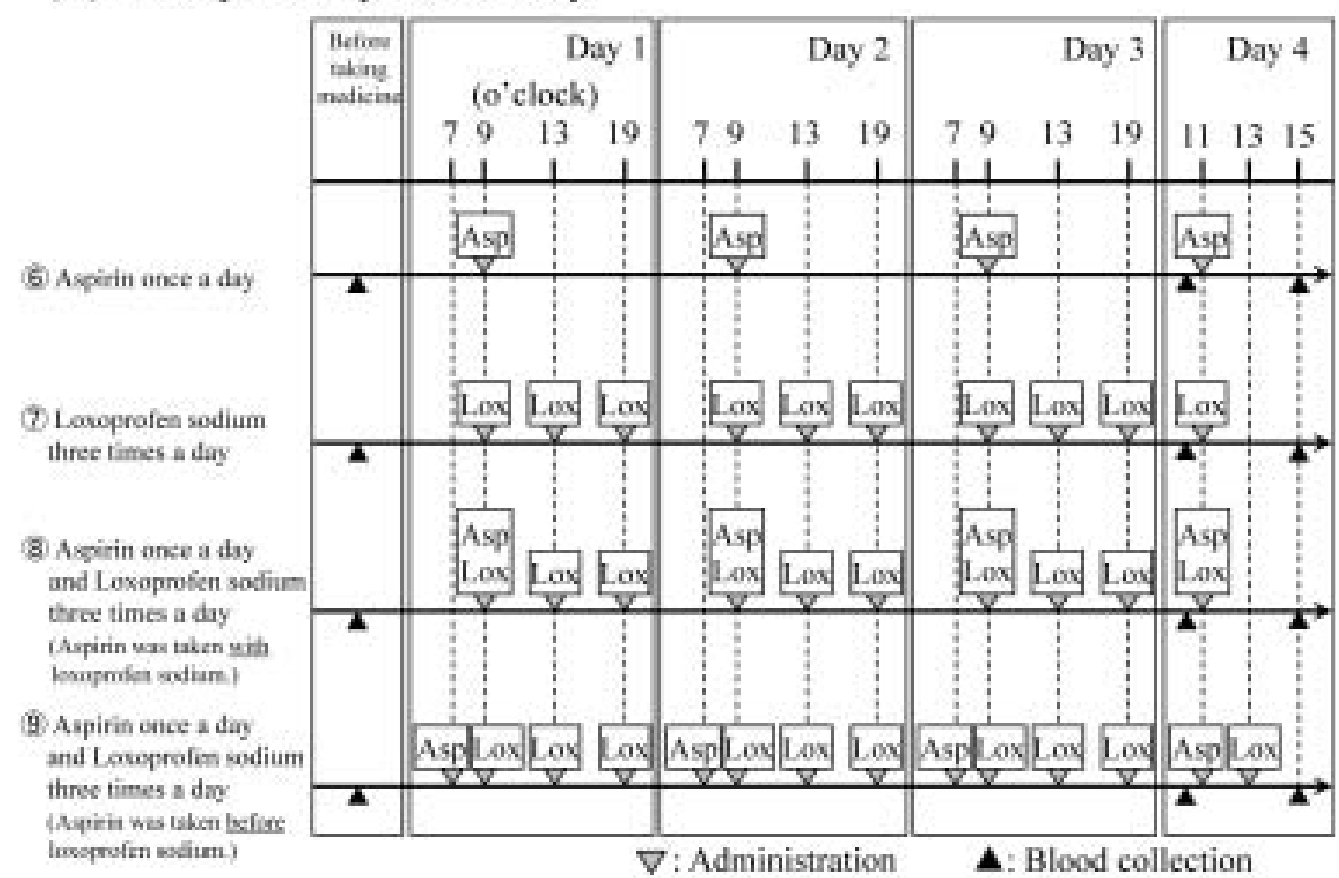

Fig 1 . Flow chart of single $(A)$ and multiple-daily-dose studies (B).

\section{4. 血小板凝集能の測定}

1)採血

被験者は，採血日前日の夕食以降，アルコールや脂肪 分の多い食事を控えた . また，血小板凝集能への影響を 最小限とするため，ホウレン草，ニンニク，ニラ，玉ね ぎ等を大量に食べたり ${ }^{13)}$, 濃いお茶を大量に飲んだりし
ないようにした ${ }^{14)}$. 食事は採血4時間前までに済ませ(4 日目の朝食は $10: 30 〜 11: 00)$ ，炎の後採血終了時まで 水以外の飲食を控えた。

採血針は $21 \mathrm{G}$ のものを用い, 1 回につき $10 \mathrm{~mL}$ 採血 した . 3.8\% クエン酸ナトリウム水溶液(1/9量)を加えて 混和後, 遠心分離(200x g, 10 分, 室温)して上層の多血 小板血漿(platelet rich plasma: PRP)を分取した.さらに 
医療薬学 Jpn. J. Pharm. Health Care Sci.

残渣を遠心分離(1700x g，15分，室温)して上層の乏血 小板血漿(platelet poor plasma : PPP)を得た .

2)血小板凝集能の測定

血小板凝集能は Born and Crossの比濁法 ${ }^{15}$ に基づき， 血小板凝集能測定装置(PRP 313 M , アイ・エム・アイ (株))を用いて測定した。PRP 1094 L に血小板凝集惹起 斉(コラーゲン溶液または ADP 水溶液)11.1 L を を加えた 後, 血小板凝集率を 5 分間測定した。血小板凝集惹起剂 の濃度は, PRP 添加後の濃度として $0.5,2,5,19 \mathrm{~g} / \mathrm{mL}$ (コラーゲン溶液)および $0.5,2,4,19 \mathrm{M}$ (A DP 水溶液) とした .この時に用いたPPPの光透過度を $100 \%$ とし た時のPRPの光透過度が血小板凝集率として記録さ れ, 光の最大凝集率を求めた。なお, PRPの凝集能は 時間経過とともに変動しやすいため, 採血から凝集能測 定開始までの時間を一定にし，測定者も限定した ${ }^{16,177}$.

\section{5. 血清中トロンボキサン $B_{2}\left(T X B_{2}\right)$ 濃度測定}

血清中 $T X B_{2}$ 濃度は醰素免疫測定法(enzymelinked immunosorbent assay：ELISA)を用いて定量した . 造血細胞 による影響を最小限にして，血小板凝集率の測定と同一 条件下でのTX的 の生成量を測定するために，コラーゲ ンで疑集反応後のPRPを用いた ${ }^{18)}$. コラーゲン $2 \mathrm{l} \mathrm{g} / \mathrm{mL}$ で5分間凝集反応させた後のPRP 10qu L を遠心分離 (2000x g，15 min，4ㄷ)して血小板を取り除き，关の上 清を用いた . 上清は分析までの間 - 30Cで保存した . Thromboxane $B_{2}$ EIA Kit(Cayman Co.)を用いて血清中 $\mathrm{TXB}_{2}$ 濃度を定量した。

6. データ解析

1)血小板凝集能

コラーゲン, ADPの 4濃度における最大凝集率 $(\%)$ を 結んで得られた線をグレーディングラインとした . 最も 高濃度であるコラーゲン $19 \mathrm{~g} / \mathrm{mL}$ ，ADP 19u M におけ
る最大凝集率を $100 \%$ とした時に，50\%の凝集に相当 するレベルとグレーディングラインの交差した点から血 小板凝集の閾値濃度(Platelet aggregation threshold index : PATI)を求め ${ }^{19)}$ ，血小板凝集能の指標とした(Fig. 2)．す なわち, PATIが上昇した時は, より高濃度の血小板凝 集惹起剂を加えないと血小板が疑集せず，血小板凝集能 が抑制されていることを意味する。

\section{2)統計処理}

医薬品服用前に対する服用後のPATI および血清中 $\mathrm{TX} \mathrm{B}_{2}$ 濃度の比較には，Dunnett 検定を用いた . 各投与群 (単回投与試験：(1)～(5)，連続投与試験：(6)～(9))で求め たPATI および血清中 TX $\mathrm{B}_{2}$ 濃度の比較には, Tukey 検 定を用い, $p<0.05$ で有意性を判定した .

\section{結果}

\section{1. 単回投与試験}

各条件におけるPATI をFig. 3 に示した. (1)Aspで は, 凝集惹起剤としてコラーゲンを用いた場合, 服用直 前のPATI が $0.90 \pm 0.2 \pi \mathrm{g} / \mathrm{mL}$ (mean \pm S.E.)であったが， 4 時間後, 24 時間後のPATI は 4.00 $0.56,2.36 \pm 0.35$ $\mu \mathrm{g} / \mathrm{mL}$ であり，血小板凝集の抑制がみられた $(4 \mathrm{hr}: \mathrm{p}<$ $0.01,24 \mathrm{hr}: p<0.05)$. 各条件における4 時間後におい ては, (2)Lox と (5)Lox $\rightarrow$ A sp の PATI は(4)A sp $\rightarrow$ Lox より も低かったが，(1)A sp と比較すると(2)〜(5)のいずれの服 用条件ともPATI はあまり変わらなかった . 24 時間経過

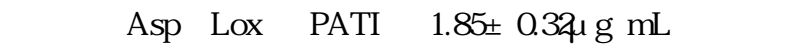
(1)Asp と同程度の值を示したが , (2)Lox(0.98 0.291 g/ $\mathrm{mL})$, (3)A sp + Lox (1.10 $\pm 0.24 \mu \mathrm{g} / \mathrm{mL})$, (5) Lox $\rightarrow A \mathrm{sp}(1.02$ $\pm 0.39 \mathrm{~g} / \mathrm{mL})$ ) PATIは, (1)Aspよりも低い値となり( <0.05), アスピリンの抗血小板作用の減弱がみられ た。一方，凝集惹起剂としてADPを用いた場合は，い ずれの時間においても各服用条件間のPATI は同程度で

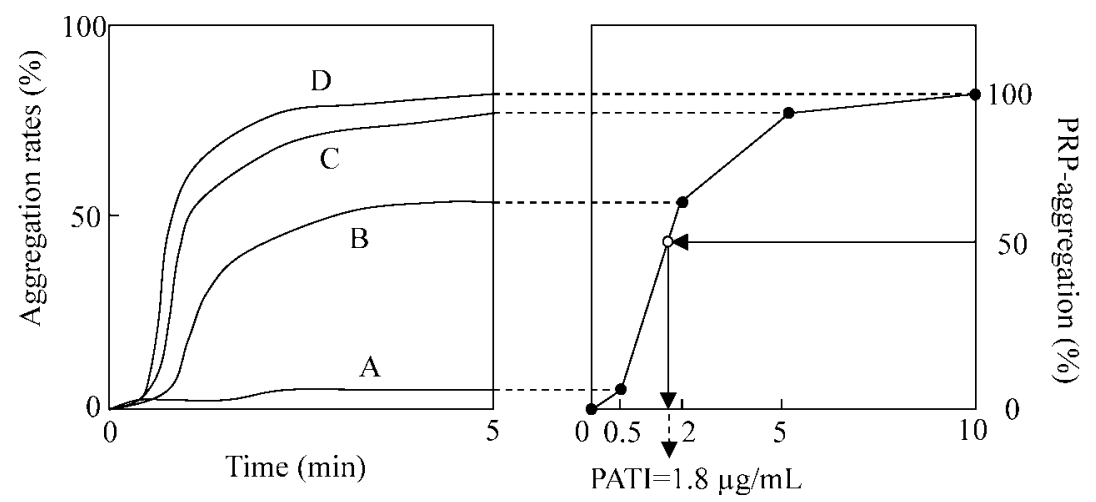

Platelet aggregation stimulus (collagen: $\mu \mathrm{g} / \mathrm{mL}$, or ADP: $\mu \mathrm{M}$ )

Fig 2. Calculation method of platelet aggregation threshold index (PATI). Light transmission curves were obtained with four concentrations of stimulus (collagen, A : 0.5, B : 2, C : $5, \mathrm{D}: 19 \mathrm{~g} / \mathrm{mL}, \mathrm{ADP}$, $A: 0.5, B: 2, C: 4, D: 16 \mu \mathrm{M})$. 


\section{(A) Collagen Stimulated}

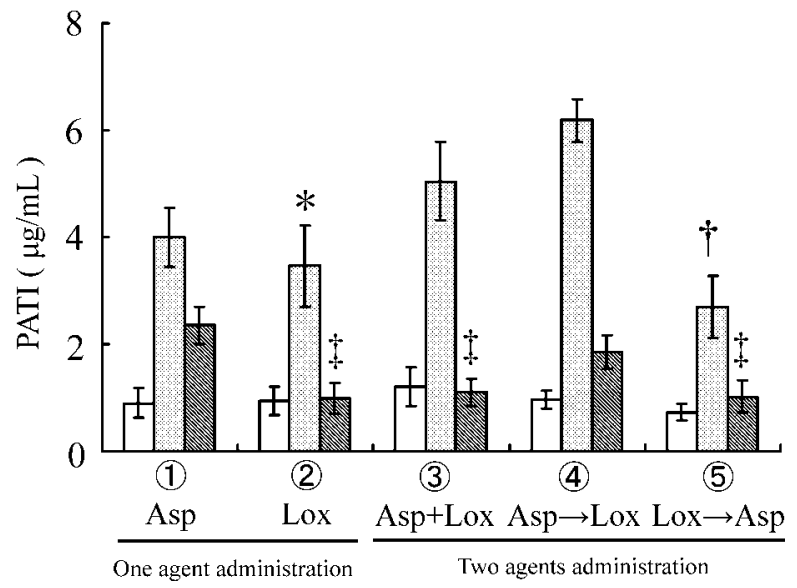

(B) ADP Stimulated

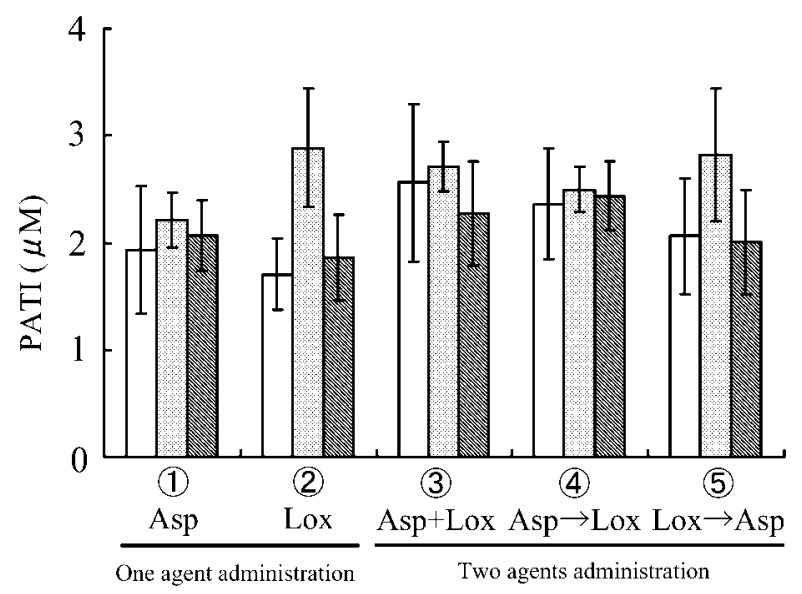

Fig 3. Collagen-induced (A) or ADP-induced (B) platelet aggregation in five conditions with single daily dose. White bars mean before administration, light gray bars mean 4 hours after aspirin, and dark gray bars mean 24 hours after as pirin $(n=11$, mean \pm S.E.). In taking only loxoprofen sodium, each bar means before taking loxoprofen sodium, 4 and 24 hours after loxoprofen sodium. $(*: \mathrm{p}<0.05$ versus (4) A sp $\rightarrow$ Lox $, \dagger: p<0.01$ versus (4)A sp $\rightarrow$ Lox,$\ddagger$ : $p<0.05$ versus (1) A sp)

あった .

(1)A sp における血清中 TX $\mathrm{B}_{2}$ 濃度は, 服用直前では 104.6 $\pm 18.9 \mathrm{ng} / \mathrm{mL}$ (mean \pm S.E.)であつた . 4 時間後， 24 時間後では光れ光れ $7.4 \pm 2.3 \mathrm{ng} / \mathrm{mL}, 13.3 \pm 2.5 \mathrm{ng} / \mathrm{mL}$ となり，24 時間後まで $T X B_{2}$ は低濃度であり $(p<0.01)$ ， COX-1の阻害が持続していると考えられた . 24 時間後 において , (4)A sp $\rightarrow$ Lox の TXB 2 は $17.0 \pm 3.0 \mathrm{ng} / \mathrm{mL}$ であ

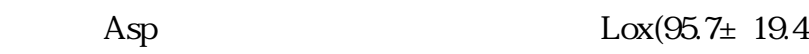
$\mathrm{ng} / \mathrm{mL})$, (3)A sp + Lox (71.3 $18.1 \mathrm{ng} / \mathrm{mL})$ の血清中 $T X B_{2}$ 濃度は, アスピリン単剂服用よりも高く(2)Lox : $p<$ 0.01 , (3) A sp + Lox : p<0.05)，ほぼ服用直前の濃度に
(1) Serum $\mathrm{TXB}_{2}$ concentration (0hr)

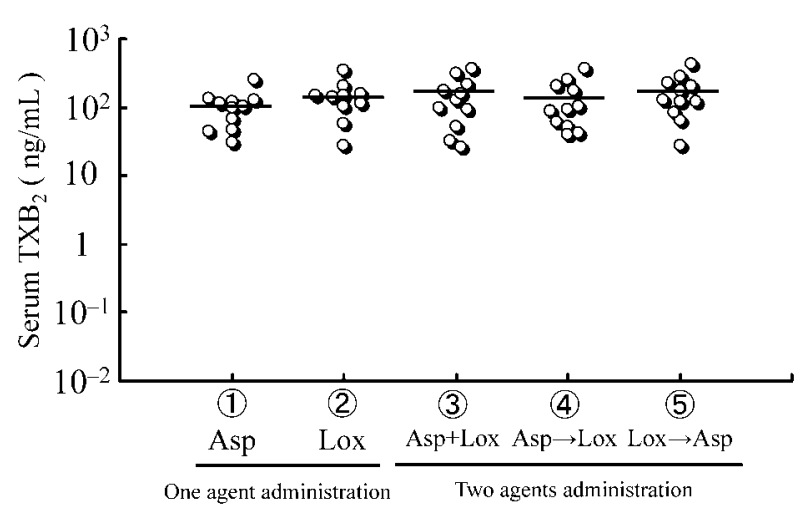

(2) Serum TXB 2 concentration (4hr)

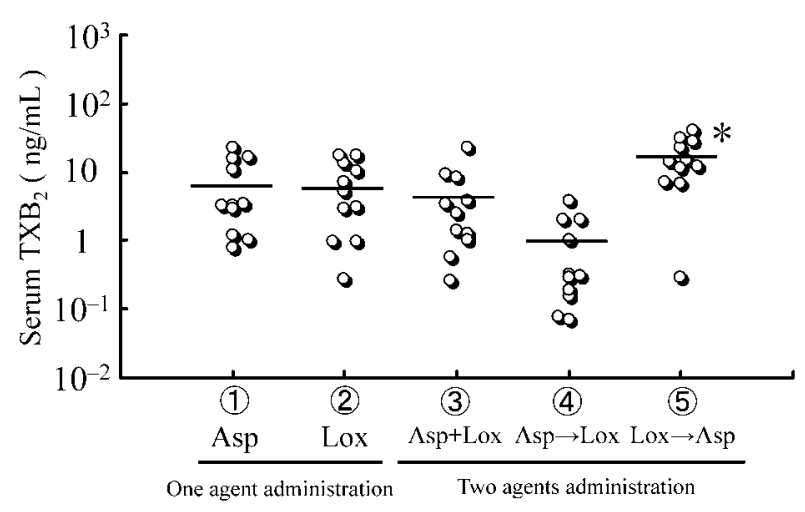

(3) Serum $\mathrm{TXB}_{2}$ concentration (24hr)

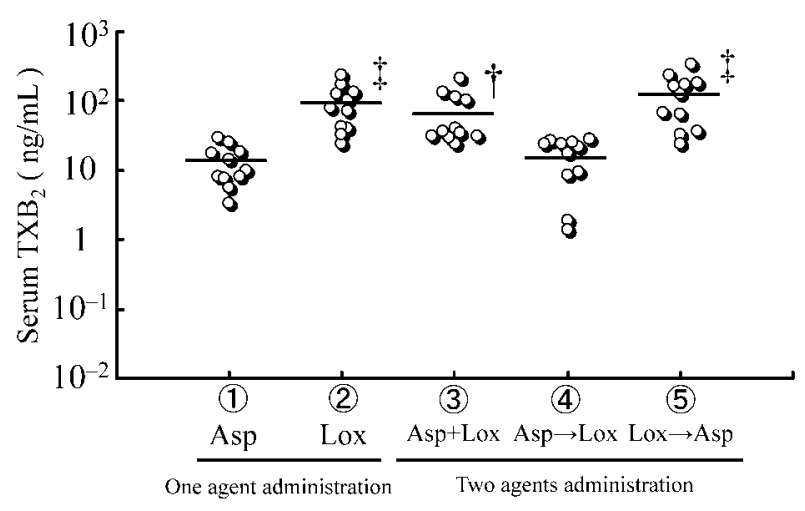

Fig 4 . Serum $\mathrm{TXB}_{2}$ concentration in five conditions with single daily dose $(n=11)$. The individual data points with a line for the mean were re ported. ( $*: p<0.05$ versus (1) Asp and (2) Lox, $p<0.01$ versus (3)A sp + Lox and (4) $A s p \rightarrow$ Lox $, \dagger: p<0.05$ versus (1)A sp,$\ddagger$ : $\mathrm{p}<0.01$ versus (1)A sp and (4)A sp $\rightarrow$ Lox).

戻った(Fig. 4). (5)Lox $\rightarrow A$ sp の血清中 $T X B_{2}$ 濃度は , 4 時間後, 24 時間後ともに(1)A sp よりも高濃度であった(4 hr : p $<0.05,24 \mathrm{hr}: \mathrm{p}<0.01)$. 
医療薬学 Jpn. J. Pharm. Health Care Sci.

\section{2. 連続投与試験}

各条件におけるPATI を Fig. 5 に示した . 6A A sp 連続 の条件では，凝集惹起剂としてコラーゲンを用いた場 合，服用前のPATI が $1.81+0.33 \mathrm{~g} / \mathrm{mL}$ であった . 4 日 目の 10 : 30(該当日のアスピリン服用前)のPATI は 5.51 $\pm 0.59 \mu \mathrm{g} / \mathrm{mL}, 15$ : 00(該当日のアスピリン服用 4 時間

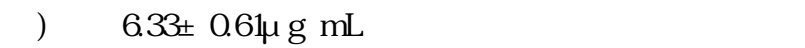
みられた $(p<0.01)$. 8)A sp + Lox 連続では ,4 日目の 10 : 30 のPATI は $2.20 \pm 0.43 \mu \mathrm{g} / \mathrm{mL}$ であり，服用前の凝集 能と同程度であった .一方，(9)A sp $\rightarrow$ Lox 連続では，4

\section{(A) Collagen Stimulated}

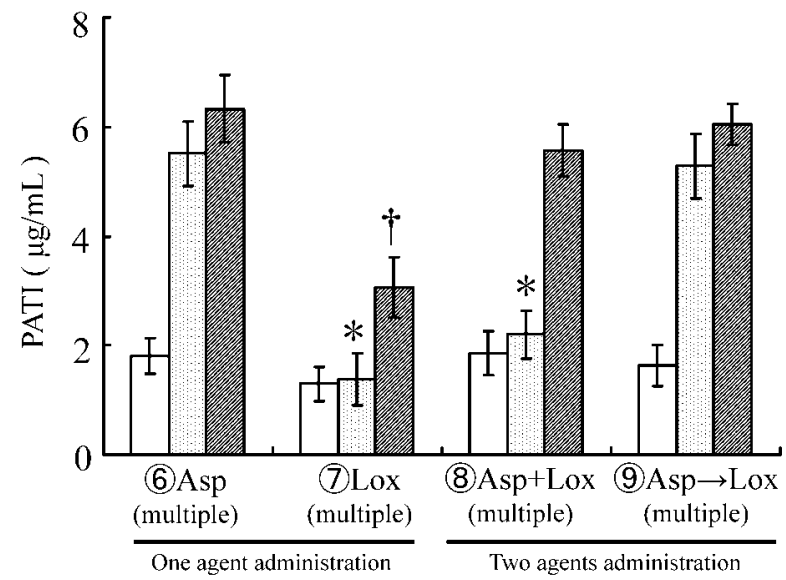

(B) ADP Stimulated

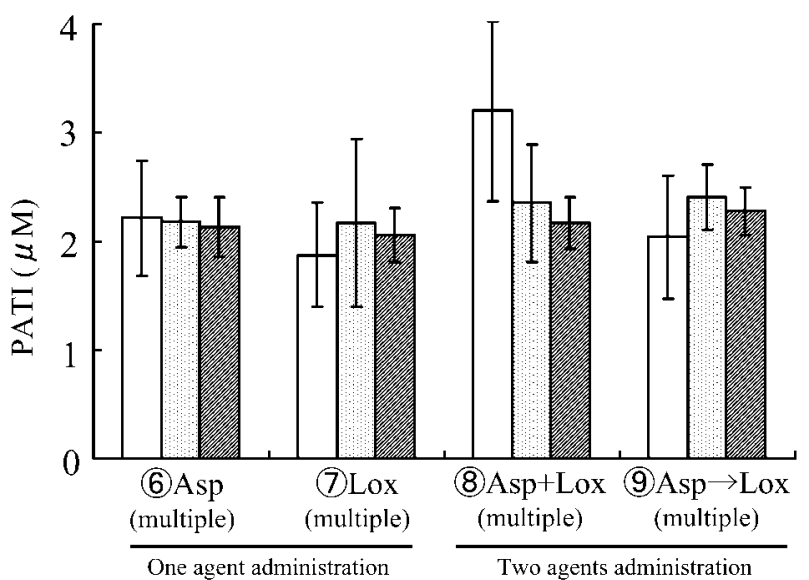

Fig 5. Collagen-induced (A) or ADP-induced (B) platelet aggregation in four conditions with multiple daily doses. White bars mean before administration, light gray bars mean before first administration of day 4 , and dark gray bars mean 4 hours after aspirin $(n=10$, mean $\pm S$. E.). In taking only loxoprofen sodium, a dark gray bar means 4 hours after taking loxoprofen sodium. ( $*: p<0.01$ versus (6)A sp [multiple] and (9)A sp $\rightarrow$ Lox [multiple] $, \dagger: p<0.01$ versus (6)A sp [multiple] and (9) $A s p \rightarrow L o x$ [multiple], $p<0.05$ versus (8)A sp + Lox [multiple])

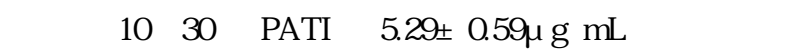
A sp 連続における凝集能と変わらなかった . また，(7)

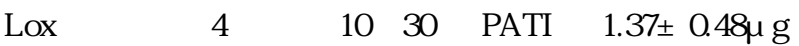
$\mathrm{mL}$ であり，服用前の凝集能に近い值を示した．なお， 凝集惹起剂として ADP を用いた場合は，いずれの時間 においても各服用条件間のPATI は同程度であった .

4 日目の 10 : 30(該当日のアスピリン服用前)における 血清中 $T X B_{2}$ 濃度は，6Asp 連続では $0.8 \pm 0.2 \mathrm{ng} / \mathrm{mL}$ ， (9)A sp $\rightarrow$ Lox 連続では 1.4 $0.4 \mathrm{ng} / \mathrm{mL}$ であったが , 8)A sp + Lox 連続では $56.1+13.2 \mathrm{ng} / \mathrm{mL}$ と高濃度であり(Fig. 6, p<0.01)，COX-1の阻害が減弱していると考えられ

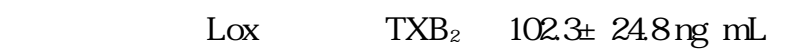
あり，医薬品服用前と変わらなかった．4日目の $15: 00$ (該当日のアスピリン服用 4 時間後)における $T X B_{2}$ は， 単回投与試験の場合と同樣に低下したが，(7)Lox 連続の $\mathrm{TXB}_{2}$ は 8.4 $2.3 \mathrm{ng} / \mathrm{mL}$ であり，(6)A sp 連続より高濃度 であった $(p<0.01)$.

\section{考察}

代表的な抗血小板薬である低用量アスピリンの投与中 に，NSAIDsを併用した場合，血小板凝集抑制作用が弱 まることが知られている．イブプロフェンでは作用を減

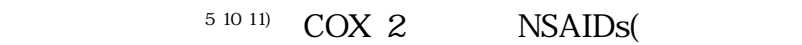
ブ(1)等)では作用を減弱させない可能性が報告されてい るが , 弚の他の NSAIDsにおける相互作用の情報は不明 であった .これまでに，アスピリンと NSAIDsのヒト血 液への薬物添加実験系において, NSAIDsの臨床用量に おける薬物濃度から血小板 COX -1 の阻害の程度を検討 することによってアスピリンと NSAIDsとの相互作用の 推測につながる可能性に言及したが20), 血漿中濃度の変 動等の他の要因も考慮する必要があると考えられた．

弚こで本研究では, わが国で繁用されているNSAIDs であるロキソプロフェンナトリウムに絞ってさまざまな 検討を行った . なお，ロキソプロフェンナトリウムを服 用すると，体内でロキソプロフェン-SRS(ロキソプロ フェンナトリウムの活性代謝物)に変換されるが, 解 熱・鎮痛・抗炎症作用も，血小板 COX-1の阻害も，口 キソプロフェン-SRSのみに認められる ${ }^{21)}$. まずアスピ リンとロキソプロフェンナトリウムを単回併用投与した 際に, アスピリン単剂服用の場合と比較して血小板凝集 能がどのように変化するか検討したところ，両方の医薬 品を同時に服用した場合，およびロキソプロフェンナト リウムを先に服用して 2 時間後にアスピリンを服用した 場合は，アスピリン単剂服用の場合よりも PATIが低く (Fig. 3-A) , アスピリンと同時または服用前にロキソプ ロフェン-SRS に曝露されると，ロキソプロフェン-SRS により抗血小板作用が減弱することが考えられた . 方，アスピリンを先に服用して 2 時間後にロキソプロ フェンナトリウムを服用した場合は, アスピリン単剂服 
(1) Serum $\mathrm{TXB}_{2}$ concentration (pre)

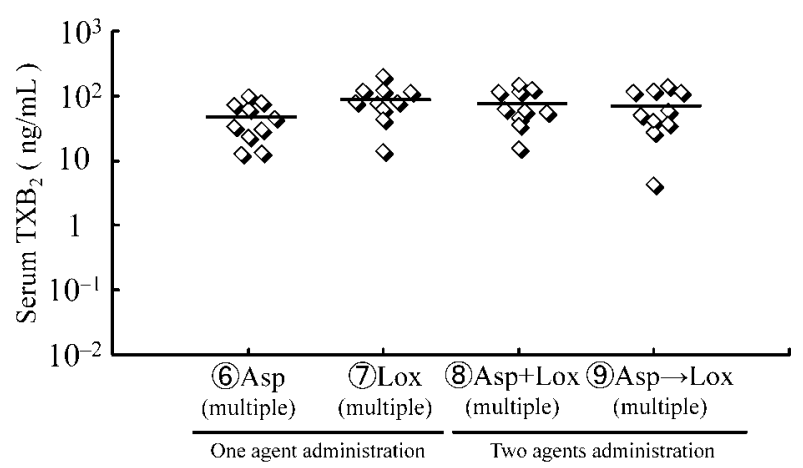

(2) Serum $\mathrm{TXB}_{2}$ concentration $(0 \mathrm{hr})$

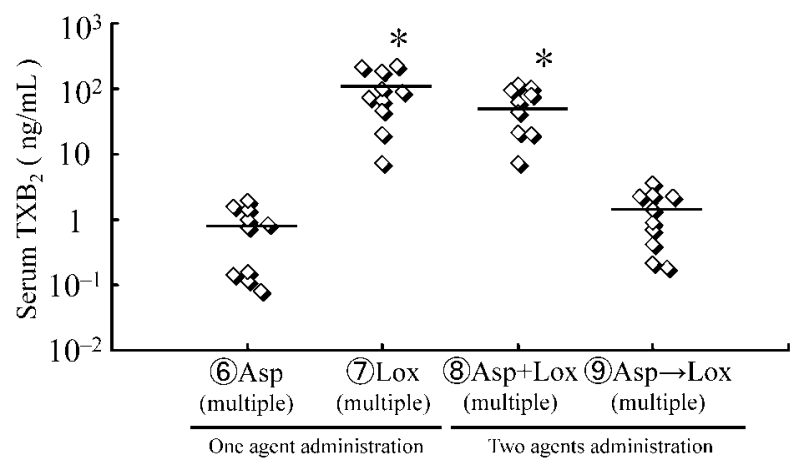

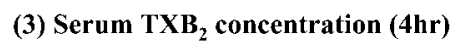

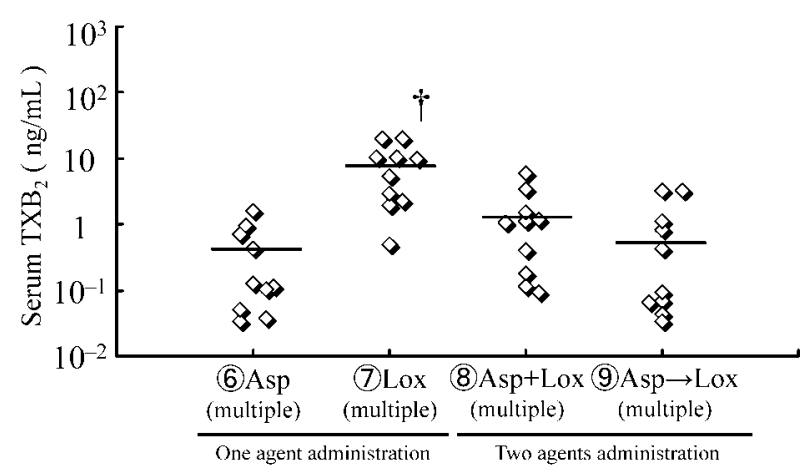

Fig .6. Serum $T X B_{2}$ concentration in four conditions with multiple daily doses $(n=10)$. The individual data points with a line for the mean were reported. ( $*: p<0.01$ versus (6)A sp [multiple] and (9)A sp $\rightarrow$ Lox [multiple] $, \dagger: p<0.01$ versus (6)A sp [multiple] , (8)A sp + Lox [multiple] and (9)A sp $\rightarrow$ Lox [multiple])

用の場合とPATI がほぼ同じであり(Fig. 3-A),アスピリ ン服用後にロキソプロフェン-SRS に曝露されても光の 影響はほとんど受けないことが示唆された．また，血清 中 $\mathrm{TX} \mathrm{B}_{2}$ 濃度も血小板凝集能と同樣の傾向を示してい た・ところで, 血漿中のアスピリンの半減期は約 15〜20

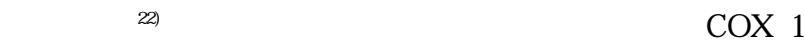

をアセチル化することで血小板凝集が抑制されると考え られている ${ }^{234}$. ロキソニン ${ }^{\circledR}$ 錠 $60 \mathrm{mg}$ を1錠服用した 時のロキソプロフェン-SRS の血漿中濃度は，0.25 時間 後に $0.19 \mathrm{~g} / \mathrm{mL} ， 0.8$ 時間後に $0.85 \mathrm{\mu} / \mathrm{mL}$ (最大血漿中濃 度), 光して 2 時間後では $0.46 \mu \mathrm{g} / \mathrm{mL}$ である ${ }^{25)}$. ロキソ プロフェン-SRS の COX $-1 \mathrm{IC}_{50}$ は 0.094 $\mu \mathrm{g} / \mathrm{mL}$ 程度であ るため ${ }^{26}$ ， ロキソニン®錠 $60 \mathrm{mg}$ を服用するとすぐにロ キソプロフェン-SRSがCOX-1を可逆的といえども十 分阻害する濃度に達すると推察され，2時間後において も阻害が持続することが考えられる，弚の結果，アスピ リンが血小板 COX-1に結合できず，アスピリン服用時 にロキソプロフェンナトリウムを同時にまたは前もって 併用投与した時には血小板凝集能が減弱したことが推察 された。

この現象は, 血小板 COX-1のアセチル化される部位 ヘアスピリンが入り込む前にNSAIDsが到達すると， NSAIDsはアスピリンの結合を競合的に阻害するといっ

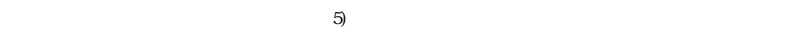
に入り込めばロキソプロフェンナトリウムの影響はほと んど受けないと考えられるが, 低用量アスピリンは通常 1日1回，ロキソプロフェンナトリウムは1日 3 回投与 されるため, 前日のロキソプロフェンナトリウムが影響 した場合，アスピリンを先に投与しても抗血小板作用が 減弱する懸念がある ${ }^{5)}$. したがって，投与回数を臨床の 用法に近づけた服用条件(連続併用試験)による検討を行 うこととした .

両方の医薬品を併用し, 朝食後にアスピリンとロキソ プロフェンナトリウムを同時に服用した場合は, 単回併 用投与の時と同樣にアスピリン単剂服用の場合よりも PATI(4日目のアスピリン服用前)が低かった .アスピリ ンとロキソプロフェン-SRS は血小板 COX-1を競合的 に阻害していることが考えられ，光の結果アスピリンの 抗血小板作用か減弱しているものと考えられた .ところ が，併用条件でも朝食後にアスピリンを先に服用して 2 時間後にロキソプロフェンナトリウムを服用した場合 は，アスピリン単剂服用の場合と PATI(4日目のアスピ リン服用前)がほぼ同じであった(Fig. 5-A) . ロキソプロ フェン-SRS の体内からの消失は 1 - コンパートメント モデルに従うと仮定すると，消失速度定数 $\mathrm{ke}_{\mathrm{e}}$ は $0.60 \mathrm{hr}^{-1}$ と求められ，ロキソニン錠 $60 \mathrm{mg}$ を服用してから 12 時間後の血漿中濃度は約 $1.1 \times 10^{-3} \mu \mathrm{g} / \mathrm{mL}$ であると計算 される ${ }^{25}$.この值はロキソニン踶 $60 \mathrm{mg}$ 単剂服用にお ける濃度を算出したものであるが, NSAIDsの血漿中濃 度は低用量アスピリン併用下においても光れほど変動し ないか若干低下する程度であると考えられ27)，ロキソプ ロフェン-SRS の COX-1 I I 50 より十分に低いことか推察 される.アスピリン服用時には, 前日の夕食後のロキソ プロフェンナトリウム服用後から 12 時間以上が経過し ており，ロキソプロフェン-SRS の理論濃度から COX-1 はほとんど阻害されていないと考えられる．したがっ 
医療薬学 Jpn. J. Pharm. Health Care Sci.

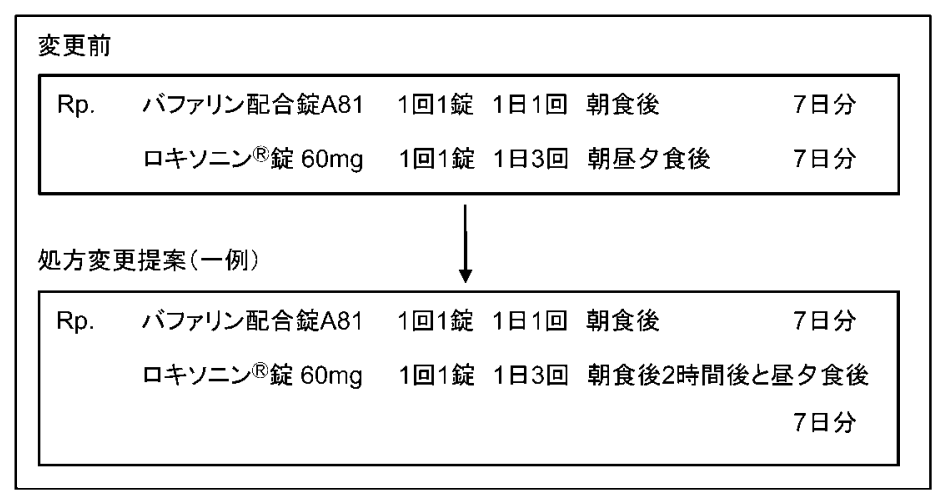

Fig .7 . Example of proposing prescription change in case of taking aspirin with loxoprofen sodium.

て , 朝食後にアスピリンを先に服用した場合は, 前日の 服薬によるロキソプロフェン-SRS の影響は受けず，光 の一方で 2 時間後のロキソプロフェンナトリウム服用時 にはすでにアスピリンのアセチル化が完了していると考 えられる。

ところで, 朝食後にアスピリンを先に服用して 2 時間 後にロキソプロフェンナトリウムを服用するという方法 は, コンプライアンスの観点からはやや複雑である . COX-2選択的 NSAIDsであるセレコキシブをアスピリ ンと併用した場合は, 朝食後に両方の医薬品を同時投与 してもアスピリンの抗血小板作用が減弱しないことが知 られている ${ }^{10)}$.しかし,わが国においてはロキソプロフェ ンナトリウムの処方頻度が高いことや ${ }^{12)}$ ，適応症が多く 薬価が安いこと等を考慮すると，低用量アスピリンの薬 物療法においてNSAIDsを併用投与する場合，ロキソプ ロフェンナトリウムが選択されるメリットがあると考え られる。

なお，単回・連続の両方の試験を通して，ADPによ る凝集では服用条件や経過時間によらず, 各群とも同程 度のPATI を示し, 血小板凝集能の変化はほとんどみら れなかった(Fig. 3-B，Fig. 5-B) . コラーゲンは血小板 内のアラキドン酸を増加させ , COX-1により TXA 2 を 産生して血小板を凝集させる惹起剂であり，ADPは血 小板のアデニル酸シクラーゼを抑制し, サイクリック AMP の産生を減少させて血小板を凝集させるが，ADP による凝集反応には COX-1は関与していないことが原 因であると考えられた .

今回の研究では, アスピリンとロキソプロフェンナト リウムとの相互作用に関する検討が主な目的であるが， ロキソプロフェンナトリウムのみ服用の場合に血小板凝 集抑制作用がみられるかに関しても測定を行った . 単回 投与試験の服用 4 時間後においては, 血小板凝集能の抑 制, 血清中 $T X B_{2}$ 濃度の低下の度合はアスピリンと同程 度(Fig. 3-A，Fig. 4)であったが，24時間後ではアスピ リンほどの作用はみられず, 服用前とあまり変わらな かった.連続投与試験においても，抗血小板作用や cox
-1阻害能はアスピリンよりはるかに弱く(Fig. 5-A，Fig. 6), ロキソプロフェンナトリウム単剤ではアスピリン治 療を代替できないと思われる．

結論として, アスピリンの抗血小板作用は, ロキソプ ロフェンナトリウムにより減弱することが示唆された が，服用方法を工夫することで炎の影響を最小限に抑え ることができると考えられた . 具体的には，臨床上よく みられる服用方法(アスピリンを1日1回朝食後，ロキ ソプロフェンナトリウムを1日3回毎食後に服用)を想 定した場合, 朝食後にアスピリンとロキソプロフェンナ トリウムを同時に服用するとアスピリンの抗血小板作用 は減弱したが, 朝食後にアスピリンを先に服用して 2 時 間後にロキソプロフェンナトリウムを服用すればこの相 互作用は回避できることが示唆された(Fig. 7).

\section{引用文献}

1) H.J. Weiss, L.M. A ledort, Impaired platelet-connective tissue reaction in man after aspirin ingestion, Lancet, 2 , 495-497 (1967).

2) H. Y asue, H. Ogawa, H. Tanaka, S. Miyazaki, R. Hattori, M. Saito, K. Ishikawa, Y. Masuda, T. Y amaguchi, T. Motomiya, Y. Tamura, Effects of aspirin and trapidil on cardiovascular events after acute myocardial infarction. Japanese A ntiplatelets Myocardial Infarction Study (JAMIS) Investigators, Am. J. Cardiol ., 83, 1308-1313 (1999).

3) Randomised trial of intravenous streptokinase, oral aspirin, both, or neither among 17,187 cases of suspected acute myocardial infarction: ISIS-2. ISIS-2 (Second International Study of Infarct Survival) Collaborative Group, Lancet, 2 , 349-360 (1988).

4) 堀正二, 池田康夫 , 石丸新 , 井上博 , 内山真一郎 , 小川 久雄，川副浩平，米田正始，住吉徹哉，中澤誠，中谷武 嗣, 野々木宏, 浅野竜太, 岩出和德, 上塚芳郎, 海北幸 一, 後藤信哉, 坂田泰彦, 坂本知浩, 佐藤直樹, 篠原徳 子，中居賢司，宮田茂樹，村㠃かがり，矢坂正弘，山内 孝, 島田和幸, 高本眞一, 友池仁暢, 永井良三, 循環器 疾患における抗凝固・抗血小板療法に関するガイドライ 
ン(2009年改訂版) ,日本循環器学会.

5) F. CatellaLawson, M.P. Reilly, S.C. Kapoor, A.J. Cucchiara, S. Demarco, B. Tournier, S.N. Vyas, G.A. Fitzgerald, Cyclooxygenase inhibitors and the antiplatelet effects of aspirin, N. Engl. J. Med., 345 , 1809-1817 (2001).

6) J.W. Burch, N. Stanford, P.W. Majerus, Inhibition of plate let prostaglandin synthetase by oral aspirin, J. Clin. Invest., 61 , 314-319 (1978).

7) G.M. Greig, D.A. Francis, J.P. Falgueyret, M. Ouellet, M.D. Percival, P. Roy, C. Bayly, J.A. Mancini, G.P. O' Neill, The interaction of arginine 106 of human prostaglandin $\mathrm{G} / \mathrm{H}$ synthase 2 with inhibitors is not a universal component of inhibition mediated by nonsteroidal anti-inflammatory drugs, Mol. Pharmacol., 52 , 829-838(1997).

8) S. Cronberg, E. Wallmark, I. Söderberg, Effect on platelet aggregation of oral administration of 10 non-steroidal analgesics to humans, Scand. J. Haematol., 33 ,155-159 (1984).

9) S. Pathmakanthan, D.G. O'Donovan, K.M. Sheehan, F.E. Murray, Prospective evaluation of the utilization of aspirin and nonsteroidal anti-inflammatory drugs in acute medical admissions, Ir. Med. J ., 91 , 58-60 (1998).

10) G. Renda, S. Tacconelli, M.L. Capone, D. Sacchetta, F. Santarelli, M.G. Sciulli, M. Zimarino, M. Grana, E. D’ A melio, M. Zurro M, T.S. Price, C. Patrono, R.De Caterina, P. Pa trignani, Celecoxib, ibuprofen, and the antiplatelet effect of aspirin in patients with osteoarthritis and ischemic heart dis ease, Clin. Pharmacol. Ther., 80 , 264-274 (2006).

11) S. Sohn, K. Kwon, Accelerated thrombotic occlusion of a medium-sized coronary aneurysm in Kawasaki disease by the inhibitory effect of ibuprofen on aspirin, Pediatr. Cardiol., 29 , 153-156 (2008).

12）伊勢雄也，室田陽右，高山幸三，成田年，鈴木勉，宋静 香, 片山志郎，平野公易，NSAIDsの術後疼痛に対する 処方状況並びに副作用発現における因子の解析, 薬学杂隹 誌, 123，613-618 (2003).

13) 小内亨, サプリメントの適正使用と午の指導, 薬局, $55,1831-1838$ (2004).

14）並木和子，茶の機能〔7〕茶の血小板凝集抑制作用，食 品と容器, 46, 320-327 (2005).

15) G.V. Born, Aggregation of blood platelets by adenosine diphosphate and its reversal, Nature, 194 , 927-929 (1962).

16）佐藤金夫，尾崎由基男，血小板凝集能検査，Thrombosis and Circulation, 12 , 345-348 (2004).

17) M. Cattaneo, A spirin and clopidogrel : efficacy, safety, and the issue of drug resistance, Arterioscler Thromb. Vasc. Biol ., 24 , 1980-1987 (2004).
18) T. Ohmori, Y. Y atomi, T. Nonaka, Y. Kobayashi, S. Ma doiwa, J. Mimuro, Y. Ozaki, Y. Sakata, A spirin resistance detected with aggregometry cannot be explained by cyclooxygenase activity : involvement of other signaling pathway(s) in cardiovascular events of aspirin-treated patients, $J$. Thromb. Haemost., 4, 1271-1278 (2006).

19) A. Tabuchi, R. Taniguchi, K. Takahashi, H. Kondo, M. Kawato, T. Morimoto, T. Kimura, T. Kita, H. Horiuchi, A Ction of aspirin on whole blood-aggregation evaluated by the screen filtration pressure method, Circ. J., 72, 420-426 (2008).

20）赤木祐貴, 柴田健太, 仁尾祐太, 谷中昭典, 樋上賀一, 嶋田修治, 青山隆夫, アスピリンの抗血小板作用に及ぼ す非ステロイド性抗炎症薬の影響に関する研究 - ヒト血 液添加実験系を用いた検討一，医療薬学，36，382-391 (2010).

21) M. Noguchi, A. Kimoto, J.K. Gierse, M.C. Walker, B.S. Zweifel, K. Nozaki, M. Sasamata, Enzymologic and pharma cologic profile of loxoprofen sodium and its metabolites, Biol. Pharm. Bull ., 28 , 2075-2079 (2005).

22) M. Rowland, S. Riegelman, P.A. Harris, S.D. Sholkoff, Absorption kinetics of aspirin in man following oral administration of an aqueous solution, J. Pharm. Sci., 61 , 379-385 (1972).

23) A.K. Pedersen, G.A. FitzGerald, Dose related kinetics of as pirin. Presystemic acetylation of platelet cyclooxygenase, $N$. Engl. J. Med., 311 , 1206-1211 (1984).

24) 山本康次郎, 阿部美由紀, 片島正貴, 山田安彦, 澤田康 文，伊賀立二，アスピリンによる抗血小板作用のPharmacodynamicsに関する情報学的研究 - 血小板中および 血管内皮細胞中シクロオキシゲナーゼ阻害作用を考慮し た Pharmacodynamic Model の構築 - , 病院薬学 ,22,133141 (1996).

25）長沼英夫，望月祐子，川原幸則，健常人におけるLoxoprofen Sodium (CS-600)経口投与後の生体内動態, 臨床 医薬， 2, 1219-1237 (1986).

26) S. Kawai, S. Nishida, M. Kato, Y. Furumaya, R. Okamoto, T. Koshino, Y. Mizushima, Comparison of cyclooxygenase 1 and -2 inhibitory activities of various nonsteroidal antiinflammatory drugs using human platelets and synovial cells, Eur. J. Pharmacol ., 347 , 87-94 (1998).

27) A. Rubin, B.E. Rodda, P. Warrick, C.M. Gruber, A.S. Ridolfo, Interactions of aspirin with nonsteroidal antiinflammatory drugs in man, Arthritis. Rheum., 16 , 635-645 (1973). 